\title{
Pengaruh Suplementasi Tepung Batang Brotowali (Tinospora crispa L) dalam Ransum terhadap Kualitas Fisik Daging Broiler pada Penyimpanan Suhu Dingin
}

\author{
Andi Kurnia Armayanti ${ }^{*}$, Nursaiba ${ }^{1}$, Muhammad Erik Kurniawan ${ }^{1}$ \\ ${ }^{1}$ Program Studi Peternakan, Fakultas Pertanian, Universitas Muhammadiyah Sinjai \\ Jl. Teuku Umar No. 8, Sinjai Utara 92611, Sulawesi Selatan, Indonesia \\ *kurnia.armayanti@gmail.com
}

\section{INFORMASI ARTIKEL}

Diterima 30 Desember 2021

Hasil revisi diterima 31

Desember 2021

Diterbitkan 31 Desember

2021

Publish online 31

Desember 2021

Kata-kata kunci:

Broiler,

Brotowali,

Suplementasi,

Kualitas Fisik Daging

\begin{abstract}
ABSTRAK
Penelitian ini bertujuan untuk mengetahui pengaruh suplementasi tepung batang brotowali (Tinospora crispa L) dalam ransum terhadap kualitas fisik daging broiler pada penyimpanan suhu dingin. Penelitian ini menggunakan Rancangan Acak Lengkap (RAL) dengan 4 perlakuan dan 4 ulangan. Perlakuan penelitian adalah level tepung botowali $0 \%, 0.5 \%, 1 \%$ dan $1.5 \%$. Parameter yang diamati adalah kualitas fisik daging yang meliputi $\mathrm{pH}$, susut masak, dan daya ikat air. Hasil penelitian ini menunjukkan bahwa penambahan tepung batang brotowali dengan level yang berbeda tidak menunjukkan perbedaan yang nyata pada kualitas fisik daging broiler selama penyimpanan suhu dingin.
\end{abstract}

\section{ABSTRACT}

This study aimed to determine the effect of brotowali (Tinospora crispa L) stem flour supplementation in the ration on the physical quality of broiler meat in cold storage. This study used a completely randomized design (CRD) with 4 treatments and 4 replications. The research treatments were botowali flour levels $0 \%, 0.5 \%, 1 \%$ and $1.5 \%$. The parameters observed were the physical quality of the meat which included $\mathrm{pH}$, cooking loss, and water holding capacity. The results of this study showed that the addition of brotowali flour with different levels did not show a significant difference in the physical quality of broiler meat during cold storage.

Key words:

Broiler, Brotowali,

Supplementation, Meat physical Qualities 


\section{PENDAHULUAN}

Peternakan adalah salah satu cabang ilmu pertanian yang memegang peranan vital dalam pemenuhan kebutuhan protein hewani masyarakat. Peningkatan populasi penduduk serta tingkat pengahasilan masyarakat, mengakibatkan peningkatan permintaan pangan hewani. Meningkatnya daya beli masyarakat mengharuskan produsen untuk memproduksi daging broiler yang bukan hanya empuk dagingnya, ekonomis harganya, rasanya tetap enak, mudah didapatkan, namun tetap harus memiliki nutrisi tinggi serta aman bagi konsumen. Selain itu, kesadaran konsumen tentang perlunya protein hewani dan keadaan masyarakat dalam sektor sosial ekonomi mengakibatkan permintaan protein yang bersumber dari ternak kian meningkat, sehingga mengharuskan produsen melakukan peningkatan produksi di sektor peternakan. Berhubungan dengan semakin cerdasnya konsumen, mereka juga semakin hati-hati dalam memilih hasil peternakan termasuk karkas broiler.

Peternakan broiler pada umumnya rentan terkena penyakit yang dipicu oleh bakteri, virus, lingkungan parasit, jamur, dan defisensi kandungan nutrisi (Tamalluddin, 2012). Penggunaan antibiotik ataupun hormon untuk untuk growth promoter pada broiler dapat menimbulkan efek samping pada manusia yang mengonsumsinya. Hal ini disebabkan kandungan suplemen yang dikonsumsi oleh tubuh broiler tidak bisa seluruhnya dikeluarkan dari organ sekresi dan akan tersimpan dalam jaringan tubuh.

Di sisi lain konsumen menginginkan daging yang memiliki nutrisi baik serta tetap aman untuk dikonsumsi. Tentunya hal ini memacu para pakar nutrien ayam untuk bisa menemukan alternatif pakan tambahan yang dapat tetap menjaga kualitas, tersedia secara kontinyu, mudah didapatkan, serta terbukti berguna bagi ayam itu sendiri. Di Negara kita sendiri tersedia banyak alternatif bahan dan tanaman obat yang dapat digunakan untuk meningkatkan kualitas daging broiler, salah satunya dengan suplementasi fitobiotik dalam pakan.

Kualitas fisik daging sangat menentukan akseptabilitas konsumen yang dapat dipengaruhi oleh pakan (Sami et al., 2004; Soeparno, 2005; Mullen et al., 2006). Tanaman herbal yang dapat dijadikan fitobiotik adalah tepung brotowali. Tanaman ini banyak mengandung alkaloid, saponin, dan tannin. Penelitian sebelumnya oleh Supomo et al. (2016) bahwa pemberian ekstrak tumbuhan memberikan pengaruh yang nyata pada mutu ayam pedaging. Pemberian bahan herbal pada pakan mampu meningkatkan kualitas karkas broiler (Nur dan Sari, 2020). Dengan melihat potensi yang dimiliki tepung brotowali maka penulis tertarik untuk melaksanakan penelitian lebih lanjut mengenai kualitas daging broiler dengan suplementasi tepung brotowali dalam ransum. Penelitian ini bertujuan untuk mengetahui pengaruh suplementasi tepung batang brotowali dalam ransum terhadap kualitas fisik daging selama penyimpanan suhu dingin.

\section{METODE PENELITIAN}

\section{Rancangan Penelitian}

Rancangan penelitian ini adalah Rancangan Acak Lengkap (RAL) dengan 4 perlakuan dan 4 ulangan. Setiap unit percobaan terdiri dari 4 ekor ayam, sehingga jumlah keseluruhan adalah 64 ekor ayam broiler. Susunan perlakuan terdiri atas 4 macam ransum, yaitu:

$\mathrm{P} 0=$ Pakan tanpa suplementasi fitobiotik tepung batang brotowali

$\mathrm{P} 1=$ Pakan dengan suplementasi fitobiotik tepung batang brotowali $0.5 \%$

$\mathrm{P} 2=$ Pakan dengan suplementasi fitobiotik tepung batangbrotowali $1 \%$

$\mathrm{P} 3=$ Pakan dengan suplementasi fitobiotik tepung batang brotowali $1.5 \%$ 


\section{Prosedur Penelitian}

\section{Penyiapan Kandang}

Kandang yang digunakan yaitu kandang baterai. Sanitasi kandang menggunakan larutan desinfektan dilakukan sebelum datangnya day old chick (DOC). Perabotan kandang wadah pakan dan gallon air sebelumnya dicuci dengan desinfektan, lalu dibilas memakai air. Indukan buatan menggunakan lampu 15 watt yang ditempatkan pada tiap flock kandang.

\section{Penyiapan Ransum}

Batang brotowali dikeringkan dan dihaluskan hingga berbentuk tepung. Ransum disusun dalam bentuk tepung (mash) karena disukai oleh ayam dan lebih mudah diserap oleh usus sehingga efisiensinya lebih baik serta dapat diberikan ke semua umur ayam, ransum yang disusun dari dedak, jagung, konsentrat, mineral dan disuplementasi fitobiotik sesuai perlakuan dicampur sampai homogen dengan formulasi ransum pada tabel berikut.

Tabel 1. Formulasi Pakan Broiler

\begin{tabular}{|c|c|c|c|c|}
\hline \multirow[t]{2}{*}{ Bahan } & \multicolumn{4}{|c|}{ Kandungan nutrisi } \\
\hline & $\begin{array}{l}\text { PK } \\
(\%)\end{array}$ & $\begin{array}{l}\text { SK } \\
(\%)\end{array}$ & $\begin{array}{l}\mathrm{LK} \\
(\%)\end{array}$ & $\begin{array}{l}\mathrm{EM} \\
(\mathrm{Kkal} / \mathrm{kg})\end{array}$ \\
\hline Konsentrat & 35 & 8 & 3 & 2500 \\
\hline $\begin{array}{l}\text { Dedak } \\
\text { padi }\end{array}$ & 11 & 8 & 8.2 & 2700 \\
\hline $\begin{array}{l}\text { Jagung } \\
\text { giling }\end{array}$ & 9 & 2.2 & 4.1 & 3360 \\
\hline $\begin{array}{l}\text { Tepung } \\
\text { brotowali }\end{array}$ & 11.49 & $\begin{array}{l}21.1 \\
5\end{array}$ & 1.84 & 2750 \\
\hline
\end{tabular}

Sumber : Hasil Analisis Proksimat Laboratorium Kimia Pakan Ternak Universitas Hasanuddin

Keterangan: $P K$ : protein kasar, SK : serat kasar, LK: lemak kasar dan EM: energi metabolisme
Tabel 2. Formulasi dan Kandungan Pakan Komplit

\begin{tabular}{lcccc}
\hline \multicolumn{1}{c}{ Komposisi } & \multicolumn{4}{c}{ Perlakuan } \\
\cline { 2 - 5 } \multicolumn{1}{c}{ Pakan } & P0 & P1 & P2 & P3 \\
\hline $\begin{array}{l}\text { Bahan Pakan } \\
\text { (\%) : }\end{array}$ & & & & \\
Konsentrat & 40 & 40 & 40 & 40 \\
Dedak Padi & 30 & 30 & 30 & 30 \\
Jagung Giling & 30 & 30 & 30 & 30 \\
Tepung & - & 0,05 & 1 & 1,5 \\
Brotowali & & & & \\
Kandungan & & & & \\
Nutrien (\%) : & & & & \\
Protei Kasar & 20 & 20 & 20 & 20 \\
$\begin{array}{l}\text { Serat Kasar } \\
\text { Lemak Kasar }\end{array}$ & 6,3 & 6,3 & 6,3 & 6,3 \\
$\begin{array}{l}\text { Energi } \\
\text { Metabolisme }\end{array}$ & 2818 & 4,9 & 4,9 & 4,9 \\
(KkaL/Kg) & & & & \\
\hline
\end{tabular}

\section{Pemeliharaan Broiler}

DOC ditempatkan dalam kandang indukan lalu diberi air minum air gula 5\% dan lampu penghangat, suhu pemeliharaan sekitar $30^{\circ} \mathrm{C}-32^{\circ} \mathrm{C}$. Selanjutnya diberikan vaksin ND (Newcstle Disease) pada empat hari pertama melalui tetes mata dan ayam diberi pakan adaptasi selama 14 hari dan diberikan vaksin gumburo. Setelah 14 hari masa adaptasi, ayam broiler ditempatkan dengan teracak ke dalam 4 perlakuan dan 4 ulangan sehingga terdapat 16 kandang percobaan, pada hari ke 21 dilakukan vaksin AI (Avian Influenza). Broiler dipelihara selama 38 hari dan diberikan pakan perlakuan dan air minum secara adlibitum hingga panen.

\section{Penyimpanan Daging Broiler Pasca Penyembelihan}

Daging broiler bagian dada dimasukkan ke dalam lemari pendingin dengan suhu $4{ }^{\mathrm{O}} \mathrm{C}$ selama 14 hari. Daging ayam yang telah disimpan kemudian dibersihkan dan dipotong menjadi beberapa bagian sesuai kebutuhan dalam penelitian. 


\section{Parameter Penelitian}

Parameter yang diamati dalam penelitian ini yaitu $\mathrm{pH}$ daging yang diukur menggunakan $\mathrm{pH}$ meter, susut masak dan daya ikat air (DIA) daging. Tahapan pengujian susut masak daging yaitu sampel daging $20 \mathrm{~g}$ dibungkus menggunakan plastik cetik lalu dimasukkan dalam water bath dengan suhu $70{ }^{\circ} \mathrm{C}$ selama $1 / 2$ jam. Sampel diangkat kemudian didinginkan memakai air dingin yang mengalir. Kemudian sampel dikeluarkan dari kemasan plastik dan dikeringkan dengan kertas hisap. Setelah itu daging ditimbang dan susut masak dihitung dengan rumus (Kouba, 2003):

$$
\frac{\text { bobot daging sebelum pemasakan }}{\text { Bobot daging setelah pemasakan }} \times 100
$$

Pengujian daya ikat air pada daging dilakukan dengan metode tekanan atau press method (Soeparno, 2005). Sampel daging 0.3 $\mathrm{g}$ ditutup menggunakan kertas saring kemudian ditekan dengan bantuan dua plat dengan beban seberat $35 \mathrm{~kg}$ dalam waktu 5 menit. Kertas saring disimpan di bawah kertas kalkir kemudian menggambar area yang telah terbentuk. Daya Ikat Air dihitung dengan rumus sebagai berikut (Kisseh et al., 2009):

$$
D I A=\frac{\mathrm{D}}{\mathrm{T}} X 100
$$

Keterangan:

$\mathrm{D}=$ Luas Area sampel

$\mathrm{T}=$ Luas Area total

\section{Analisis Data}

Data yang diperoleh diolah menggunakan analisis sidik ragam dengan model matematika sebagai berikut:

Keterangan:

$$
Y i j=\mu+\alpha i+\epsilon i j
$$

Yij =Hasil pengamatan dari peubah pada penggunaan tepung brotowali ke-i dengan ulangan

$\begin{array}{ll}\text { ke-j } \\ \mathrm{M} & =\text { Rata-rata pengamatan } \\ \text { ai } & \text { Pengaruh perlakuan tepung } \\ & \text { brotowali } \\ & =\text { Pengaruh galat percobaan dari } \\ & \text { perlakuan } \mathrm{ke}-\mathrm{i}(\mathrm{i}=1,2,3,4) \text { dan } \\ & \text { ulangan } \mathrm{ke}-\mathrm{j}(\mathrm{j}=1,2,3,4)\end{array}$

\section{HASIL DAN PEMBAHASAN}

\section{pH Daging Broiler}

Hasil data penelitian pengaruh suplementasi tepung batang brotowali dalam ransum terhadap kualitas fisik daging broiler pada penyimpanan suhu dingin terhadap nilai $\mathrm{pH}$ daging dapat dilihat pada Tabel 3.

Tabel 3. Rataan nilai $\mathrm{pH}$ daging broiler pada berbagai perlakuan

\begin{tabular}{lc}
\hline Perlakuan & $\mathrm{pH}$ \\
\hline P0 & $5.3 \pm 0.26$ \\
P1 & $5.1 \pm 0.12$ \\
P2 & $5.2 \pm 0.21$ \\
P3 & $5.0 \pm 0.26$ \\
\hline
\end{tabular}

Hasil analisis menunjukkan bahwa suplementasi tepung brotowali tidak berpengaruh nyata $(\mathrm{P}>0,05)$ terhadap nilai $\mathrm{pH}$ daging broiler yang disimpan pada suhu dingin selama 14 hari. Hal ini didasari karena kandungan nutrisi pada setiap perlakuan memiliki nilai serat kasar yang sama antar perlakuan P1 sampai dengan perlakuan P3 yaitu $6.3 \%$ (Tabel 2) sehingga menghasilkan nilai $\mathrm{pH}$ yang relatif sama juga. Hal ini sejalan dengan pernyataan Soeparno (2005) menyatakan bahwa salah serat kasar pada pakan berpengaruh terhadap nilai $\mathrm{pH}$ daging. Selain itu, konsumsi pakan juga dapat berpengaruh terhadap $\mathrm{pH}$ daging. Broiler yang mengonsumsi konsentrat dalam jumlah yang rendah dan pakan dengan serat tinggi menghasilkan nilai $\mathrm{pH}$ daging yang lebih tinggi dari pada ternak yang mengkomsumsi pakan konsentrat tinggi serta rendah serat. 
Pada data penelitian ini kisaran nilai $\mathrm{pH}$ daging yaitu 5.0-5.3, dengan $\mathrm{pH}$ rata-rata 5.2, Hal ini sesuai dengan pernyataan Soeparno (2009) yang mengatakan bahwa nilai $\mathrm{pH}$ daging 5.2 atau dibawahnya maka perkembangan mikroorganisme menurun jika nilai $\mathrm{pH}$ ultimat besar maka perkembangan mikroorganisme kian meningkat. Menurut Situmorang (2008) bahwa aktivitas mikroorganisme selama penyimpanan menyebabkan terjadinya dekomposisi zat kimia pada karkas, terkhusus protein akan pecah menjadi zat yang lebih sederhana. Angka ini lebih rendah dari yang di dapatkan Suradi (2012) yakni 6.31 pada 0 jam paska pemotongan dan 6.24 pada 2 jam paska pemotongan.

Penurunan $\mathrm{pH}$ disebabkan karena adanya aktivitas mikroba yang menyebabkan tahapan glikolisis dan pola TCA (tricarboxylic) meningkat, akumulasi pembuatan asam laktat yang bersumber dari asam piruvat agak banyak mengakibatkan semakin rendahnya $\mathrm{pH}$ karkas broiler. Sejalan dengan apa yang dikatakan Suradi (2012) terjadi pengurangan nilai $\mathrm{pH}$ karkas broiler serta jangka waktu semakin lama setelah pemotongan, selain itu terjadi tahapan glikolisis dengan tanpa udara yang memproduksi asam laktat, dampaknya terjadi pengurangan $\mathrm{pH}$ sehingga $\mathrm{pH}$ karkas kian menjadi asam (Sams, 2001). Hasil percobaan Taklim et al. (2013) dengan perlakuan suplementasi pokem pada pakan, nilai $\mathrm{pH}$ karkas broiler adalah 5.22 sampai 5.28.

\section{Susut Masak Daging Broiler}

Hasil penelitian pengaruh suplementasi tepung batang brotowali pada ransum terhadap kualitas fisik daging broiler pada penyimpanan suhu dingin terhadap susut masak daging dapat ditinjau pada Tabel 4.

Hasil penelitian menunjukkan bahwa suplementasi tepung batang brotowali tidak berpengaruh nyata $(\mathrm{P}>0,05)$ terhadap nilai susut masak daging broiler yang di simpan pada suhu dingin selama 14 hari. Nilai susut masak daging berkisar antara 7.25-10.37 hasil yang telah didapatkan masih tergolong normal. Menurut Soeparno (2005), nilai susut masak daging biasnya antara 1.5 sampai $54.5 \%$ dengan berkisar 15 sampai $40 \%$.

Tabel 4. Rataan nilai susut masak daging broiler pada berbagai perlakuan

\begin{tabular}{lc}
\hline Perlakuan & Susut masak( \%) \\
\hline P0 & $7.25 \pm 3.30$ \\
P1 & $10.37 \pm 2.09$ \\
P2 & $9.50 \pm 2.67$ \\
P3 & $9.75 \pm 1.44$ \\
\hline
\end{tabular}

Besarnya susut masak dipengaruhi oleh $\mathrm{pH}$, panjang sarkomer serabut otot, panjang potongan serabut otot, status kontraksi miofibril, ukuran dan berat sampel daging serta penampang melintang daging ayam. Persentase susut masak daging broiler yang rendah memiliki kualitas nutrisi yang lebih baik daripada persentase susut masak daging broiler yang tinggi, karkas dalam total susut masak yang rendah mempunyai kualitas agak lebih baik disebabkan karena berkurangnya nutrisi saat pemasakan akan lebih rendah (Soeparno, 2009). Menurut Soeparno (2005) komsumsi ransum dapat mempengaruhi besarnya susut masak.

Nilai susut masak yang tidak berpengaruh nyata ini berbanding lurus dengan nilai daya ikat air yang tidak berpengaruh nyata antar perlakuan. Menurut Suradi (2006), susut masak juga disebabkan oleh nilai $\mathrm{pH}$ yang dikuti oleh kemampuan jaringan otot dalam mengikat air. Nilai susut masak broiler pada penelitian sebelumnya lebih rendah yaitu 2.25-3.88 (Nur dan Sari, 2020).

\section{Daya Ikat Air Daging Broiler}

Berdasarkan hasil penelitian diperoleh bahwa suplementasi tepung brotowali tidak berpengaruh nyata $(\mathrm{P}>0,05)$ terhadap daya ikat air daging broiler yang disimpan pada 
suhu dingin selama 14 hari (Tabel 5). Hal ini disebabkan karena kandungan protein ransum perlakuan relatif sama, sehingga menyebabkan DIA yang tidak berpengaruh nyata. Pakan merupakan satu diantara faktor yang dapat mempengaruhi DIA karkas, perbedaan nilai daya ikat air broiler disebabkan oleh karbohidrat dan protein karkas (Ockerman,1983).

Tabel 5.Rataan Nilai Daya Ikat Air daging Broiler pada Berbagai Perlakuan.

\begin{tabular}{lc}
\hline Perlakuan & Daya Ikat Air $(\%)$ \\
\hline P0 & $19.98 \pm 3.20$ \\
P1 & $25.57 \pm 10.03$ \\
P2 & $21.22 \pm 3.87$ \\
P3 & $24.72 \pm 5.12$ \\
\hline
\end{tabular}

DIA berkisar antara 19.98-25.57\%, DIA pada penelitian ini masih berada dalam kisaran normal. Menurut Soeparno (2009), daya ikat air daging sekitar 20 sampai $60 \%$ dan menurut Komariah et al. (2009) susut masak daging sangat mempengaruhi daya ikat air daging. Semakin rendah daya ikat air suatu daging maka susut masak dagingnya semakin besar, begitu pula jika daya ikat air semakin tinggi maka nila susut masak semakin rendah. Daya ikat air semakin tinggi menunjukkan bahwa protein daging mampu mengikat air lebih banyak ketika daging masak.

\section{KESIMPULAN}

Berdasarkan hasil penelitian maka dapat disimpulkanan bahwa suplementasi tepung batang brotowali pada ransum tidak berpengaruh terhadap kualitas fisik daging $(\mathrm{pH}$, daya ikat air dan susut masak) broiler pada penyimpanan suhu dingin

\section{DAFTAR PUSTAKA}

Komariah, Rahayu, S., \& Sarjito. (2009). Sifat fisik daging sapi, kerbau, dan domba pada lama postmortem yang berbeda. Buletin Peternakan. 33(3), 183-189.

Kouba, M. (2003). Quality of organic animal products. Lives Prod. Sci., 80, 33-40.

Kisseh, C., Soarest, A.L., Rossa, A., \& Shimokomaki, M. (2009). Functional properties of PSE (pale, soft, exudative) broiler meat in the production of mortadella. Brazilian archives of Biology and Technology an International Journal. 52, 213-217.

Mullen, A.M., Stapleton, P.C., Corcoran, D., Hamill, R.M. \& White, A. (2006). Understanding meat quality through the application of genomic and proteomic approaches. Meat Sci. 74, 3-16.

Nur, K., \& Sari, A. (2020). Nilai susut masak daging ayam broiler yang diberi pakan herbal berupa kunyit. Musamus Journal of Livestock Science. 3(2), 7-11.

Ockerman, H. W. (1983). Chemistry of Meat Tissue. 10 Ed. Ohio : Department of Animal Science The Ohio State University and The Ohio Agriculture Reseach and Development Centre.

Sami, A.S., Augustini, C., \& Schwarz, F.J. (2004). Effects of feeding intensity and time on feed on performance, carcass characteristics and meat quality of Simmental bulls. Meat Sci. 67:195-201.

Sams, A. R. (2001). Poultry Meat Processing. Washington, DC: CRC Press.

Situmorang, E., N. (2008). Pengawetan Daging Ayam (Gallus gallus domesticus) dengan Larutan 
Pendingin. Skripsi. Sumatra Utara: Universitas Sumatra Utara.

Soeparno. (2005). Ilmu dan Teknologi Daging. Cetakan Ke-4. Yogyakart: Gadjah Mada University Press.

Soeparno. (2009). Ilmu dan Teknologi Daging. Gadjah Mada University Press. Yogyakart: Gadjah Mada University Press.

Supomo, E., Syamsul, S., \& Ventyrina, I. (2016). Pemanfaatan ekstrak herbal terhadap produktifitas dan mutu ayam pedaging sebagai upaya ketahanan pangan di Kalimantan timur berbasis peternakan ramah lingkungan. Jurnal Ilmiah Manuntung. 2 (1), $93-98$.

Suradi, K. (2006). Perubahan sifat fisik daging ayam broiler post mortem selama penyimpanan temperatur ruang. Jurnal Ilmu Ternak. 6(1), 23 27.
Suradi, K. (2012). Pengaruh lama penyimpanan pada suhu ruang terhadap perubahan nilai $\mathrm{pH}$, TVB dan total bakteri daging kerbau. Jurnal Ilmu Ternak. 12(2), 9-12.

Taklim, D., Rosyidi, D., \& Achmanu. (2013). Pengaruh penggunaan pokem (Setaria italica $\mathrm{sp}$.) sebagai subtitusi jagung dalam pakan terhadap kualitas fisik daging bagian dada ayam pedaging. https://fapet.ub.ac.id/wpcontent/uploads/2014/01/PengaruhPenggunaan-Pokem-Setaria-italicasp.-Sebagai-Substitusi-JagungDalam-Pakan-Terhadap-KualitasFisik-Daging-Bagian-Dada-AyamPedaging..pdf

Tamalluddin, F. (2015). Ayam broiler 22 Hari Panen lebih Untung. Jakarta: Penebar Swadaya. 